BENCE FEHÉR

\title{
BYZANTINE SWORD ART AS SEEN BY THE ARABS
}

\begin{abstract}
Summary: There are two excellent Arabic sources from the 9th and 11th centuries on sword art: the treatises of al-Kindî and al-Bîrûnî. They contain a wealth of information on Byzantine sword making. These swords can in part be assigned to the 'atîq qala $\hat{\imath}$ type, i.e. the good quality forged iron type. These double-edged swords were 4 to 5 spans long. The swords from Barbarian Europe that can be likened to Byzantine types and Byzantine sword depictions clearly show that they are in fact similar, but not identical types. There is only uncertain evidence concerning soft iron and steel swords in Byzantium.
\end{abstract}

Key words: sword, al-Kindî, al-Bîrûnî, 'atîq qala 'î, Byzantium.

Although surviving examples of early Islamic sword art are regrettably few, ${ }^{1}$ much more is known about this kind of metalwork than about that of Byzantium in the 1st millennium AD. The number of surviving swords is higher than the finds from the Byzantine empire, and we also have two excellent sources, one from the 9th century, the other from the earlier 11th century: Abû Ishâq al-Kindî's The swords and their types, extant in two manuscripts ${ }^{2}$ (unfortunately both of them are incomplete) and the chapter entitled "On iron" of the Kitâb al-Jamâhir, a treatise on metallurgy by Abû r-Rayhân al-Bîrûnî. The latter quotes Pseudo-Dimashqî, who lived in the period between the two, and retained some sections of the lost parts of Kindî's book.

These two sources reveal that close connections can be detected between Byzantine and early Arabic sword art, extending to the common usage of certain types. We may therefore assert that Byzantine and Arabic sword making developed from the same roots, at least in the 6th and 7th centuries AD, and that the Arabs adopted the

\footnotetext{
${ }^{1}$ Some very archaic swords from the 1st millennium AD are kept in Istanbul. They have not been adequately published, only an approximate description with a few illustrations can be found in STÖCKLEIN 1934 and STÖCKLEIN 1939. Unpublished examples from Nîshâbûr are also known.

${ }^{2}$ An accurate and reliable edition was based on Al-Kindî Ya'qûb b. Ishâq, As-suyûf wa ajnâsuhâ, edited by 'Abdurrahmân Zakî. Bulletin of the Faculty of Letters, Fouad I University, 14/2, 1952, 1-36 (abbreviated as Kindî in the following; introduction and notes quoted as ZAKî 1952).

${ }^{3}$ The quotations from Bîrûnî are based on the following edition: Ab̂̂ r-Rayhân al-Bîrûnî, Kitâb al-jamâhir fî ma 'rifat al-jawâhir. Edited by F. Krenkow. Haydarabad 1355/1937 (abbreviated as Bîrûnî in the following).
} 
characteristic differences and more advanced techniques of swords under Indian and East Iranian influences, rather than under ones from Southern Europe. The Arab authors knew very little about Northern European sword making, and even this meagre knowledge was restricted to the swords of the Vikings. Although the evidence in this respect is fairly reliable, they reveal hardly more than that there was little connection between Arabic and Northern European techniques. ${ }^{4}$

The authors used different sword typologies, both of them including a number of definitely 'European' types. Relevant to this study is the 'atîq ('ancient', or, according to Kindî's somewhat uncertain etymology, 'of high quality'), a steel blade according to Kindî and a forged iron one according to Bîrûnî, the shâburqân that is forged iron not alloyed, and the so-called qala $\hat{\imath}$. I shall discuss the meaning of this expression later. Swords can primarily be classified according to their alloys and lustre, and only secondarily by their shape and size.

One curious statement made by Kindî is that the 'mined' (i.e. not alloyed) swords have three classes because they include soft iron (narmâhan) swords. ${ }^{5}$ The meaning of soft iron was doubtless the same in the early Islamic period as today, as shown by a passage of Pseudo-Dimashqî that notes that this soft iron is used for making hoof nails. This would suggest that the swords made using this metal were of a very inferior quality. and India.

The text claims that the narmâhan swords came from Byzantium, the Khawârij

Bîrûnî rejects the claim that Byzantine swords had been forged from soft iron. ${ }^{6}$ He calls the Byzantine swords qala $\hat{\imath}$. He does not regard these as first-class products. His opinion is rather realistic, and quotations from old Arabic poetry support it:

The blacksmiths' Byzantium brought forth once the white one from the black fluid of iron.

and

Their heads are more solid than the rocks, so that the Byzantine qala' is nicked on them. ${ }^{8}$

This would indicate that Byzantine sword making was highly appreciated by the Arabs in the Jâhilitya. One can even assume that the 'atîq qala' $\hat{\imath}$ type described by Kindî, perhaps an 'atîq with its original meaning of an ancient sword, is partially of Byzantine origin. It is therefore worthwhile to review what we know about the qala $\hat{\imath}$

\footnotetext{
${ }^{4}$ Cp. Bîrûnî 254, 8-10. There were certain types - including the European swords - that were made of forged iron, according to Bîrûnî, or of the alloy of forged iron and soft iron, according to Kindî. There is probably no contradiction between the two, with 'alloy' meaning no more than that a narmâhan or 'woven' structure of the two iron forms was hammered into the blade at the channel. Incidentally, Bîrûnî's knowledge appears to reflect some information about the cross-bar of Viking swords and their decoration.

${ }^{5}$ For a more detailed description of narmâhan swords, cp. Kindî 36.

${ }^{6}$ Bîrûnî 248, 10.

${ }^{7}$ Quoted from al-‘Ajjâj, ibid., 248, 13.

${ }^{8}$ Quoted from al-Husayn ibn al-Hammâm al-Murrî, ibid., 11.
} 
type since precise information about the material of Byzantine swords can be gleaned from this.

Both authors use the type name qala $\hat{\imath}$, but their description is slightly different. ${ }^{9}$ According to Kindî, these blades have a more reddish lustre than the best type, the yamânî, they are 4 to 5 spans in length and a little wider than 3 digits, the surface of breaking is silver coloured, they are of equal constitution, they can contain veins. Bîrûnî reveals less about them: he simply notes that they are wide and have white blades. We can hardly reconcile these two descriptions because the width given by Kindî seems to be medium (the 'modern' yamânî and sulaymânî blades are 4 digits wide!); the 'whiteness' mentioned by Bîrûnî is a relative term, when compared to the Indian swords (Kindî notes that the lustre of the latter is blackish). But Bîrûnî realized that there was some problem with the colours since he remarks that "it is possible that this is obscure in Arab poetry due to this whiteness because there is a confusion in it." $" 10$

There is a greater problem than these technical differences. There is an essential disagreement between the two authors concerning the material of the sword. Kindî classifies it as an expressively high quality ('ancient') damascened steel type, whereas Bîrûnî claims that its material is qala' and that it is thus identical with the shâburqân. ${ }^{11}$

This is not the place to discuss the origins of this word, but in my opinion Bîrûnî's statement is grammatically well founded since qala' is the original Arabic word for forged iron. In trying to interpret this word, classical vocabulary literature varies; ${ }^{12}$ there are scarcely two sources that agree on this point and most do not know that a sword name is derived from it. The most detailed explanation can be read in Mis'ar b. Muhalhil's reports on his travels in China: the relevant passage has at least two different interpretations in five sentences, suggesting that there is little reality in the author's reasoning. Qala 'î swords are classified as an Indian type, but this is an

\footnotetext{
${ }^{9}$ Kindî’s description (Kindî 23.) is shorter, but more plausible, while Bîrûnî appears to have been more interested in the iron itself, its names, its literature, and its possible identity with the material of meteorites, than in the swords.

${ }^{10}$ Bîrûnî 248, 14-15.

${ }^{11}$ Ibid., 10 sqq.

${ }^{12}$ ZAKî, op. cit., 8, note 10, has collected the relevant data. The major interpretations are the following: (1) Nihâyat al- 'arab fí funûni l-adab 6, 205: "qala 'î is an adjective related to Qal'a, a place in the desert."; (2) Al-'Imrânî: "A place in the desert, from which the swords receive their name. ... Qal', with an ' $a$ ' in advance and afterwards without a vowel, is the name of a mine after which good tin is named. They say it is a mountain in Syria."; (3) Ibn al-Athîr: "It took its name from Qala'a, with an 'a' after the 'q' and 'l', it is a place in the desert after which swords are named." These interpretations derive the word from a toponym in the Syrian desert, and do not connect it with tin, except for 'Imrânî, but he is evidently mistaken because no one else appears to know of any relation between the so-called tin type and Syria. Bîrûnî appears to be unaware of this opinion. Other authors know only the tin type or try to derive the name of the iron from the name of the tin: (4) Jawâliqî, Ma'rib 276: "The qala'î tin is pronounced with an 'a' after the 'l', and sometimes without a vowel. It is a Persian word, its original is kalahî."; (5) Khâfijî,, Shifâ'u l-ghalîl 187: "qala ' $\hat{\imath}$, with an 'a' after the 'l', sometimes without a vowel, is kalahî Arabicized, thus said Abû Manșûr." Bîrûnî was apparently familiar with this idea, but he criticizes a derivation from geographical names.
} 
almost unique viewpoint among the sources. ${ }^{13}$ It would appear that only Bîrûnî had reliable information. ${ }^{14}$ Kindî does not discuss the origins of the word at all.

Accepting Bîrûnî's view raises a new problem in Kindî’s treatise because qala $\hat{\imath} \hat{~ s w o r d s ~ c a n n o t ~ c o n t a i n ~ l u s t r e . ~}{ }^{15}$ But this is true only in general for the shâburqân, not to mention the other unintelligible points in Kindî's definition ("their iron has neither purity, nor liquid"). Accidental lustre can be seen even on the shâburqân, ${ }^{16}$ and Kindî's words, "in some places rough, in other ones soft" are actually a very good description of the veined blades of 'ancient' swords.

However, this mistake is serious enough; one of the reasons for this might have been the prejudices in public opinion that placed a higher value on 'ancient' blades, and also that Kindî appears to have known very little about the qala 'î and fâqirûn types - or, in any case, he devoted very short passages to these and he offers no subdivisions only to those.

Unfortunately, we know very little about related sword types made by others. Bîrûnî has nothing to say concerning the swords of the Khawârij. Anyway, it is most unlikely that these had been made using an essentially different technology than the average 1 st century Islamic blades.

Although neither in this one, nor in the other related passage is it claimed that all Byzantine and Khârij swords were forged from soft iron, but no other types are mentioned. This can be explained not only by the author's minimal knowledge, but also by the possible abbreviation of the text, or perhaps by the fact that the author did not consider it important to mention in connection with a type used by the Ahl asSunna that it is found elsewhere too.

Did narmâhan swords really exist or is this type simply a mistake on Kindî's part? Unfortunately, there is no evidence to resolve this question. Not one single Khârij sword has survived, and even if there had been Indian blades made of soft iron, their percentage must have been very low. Similarly, our knowledge of Byzantine weapons is also very limited - it is practically restricted to a few depictions and literary descriptions, save for the well-known sword from Corinth. ${ }^{17}$ Some of the swords from Barbarian Europe, mostly from the Carpathian Basin, are claimed to be

\footnotetext{
${ }^{13}$ Von Rohr-SAUER, A.: Des Abû Dulaf Bericht über seine Reise nach Turkestan, China und Indien. Bonner Orientalistische Studien 20. Stuttgart 1939, 30, 60: "Afterwards I travelled from China to Kala, the first country from China on the way to India, the ships travel there, and do not go farther. There is an immense qal' $a$ there, and there is a mine of qal $\hat{\imath}$ tin in it. It exists nowhere, but in the qal' $a$ of it. The qal ' $\hat{\imath}$ swords are hammered in this qal' $a$, i.e. the Indian 'atîq $\hat{\imath}$ swords. ... There is no mine of qal ' $\hat{\imath}$ tin elsewhere, but in that qal ' $a$. The distance between it and the Chinese town of Sandâbil is 300 farsaj, and around it there are towns and broad gardens."

${ }^{14}$ The authors who assert that there is no vowel after the ' 1 ' in the word qala', are rather unreliable since the metrics of the verses quoted by Bîrûnî evidently disprove them.

${ }^{15}$ For shâburqân swords, cp. Kindî 12, 4-6: "These swords show lustre neither after the powdering, nor otherwise, and their whole iron has the same colour. They are stiff, they do not bend, do not tremble, their iron has neither purity, nor fluid. They are of strong point and variable blade, in some places rough and in some places mild."

${ }^{16}$ Ibn Faḍlân also mentions the damascening of Viking swords. HOFFMEYER, Military Equipment in the Byzantine Manuscript of Scylitzes. Gladius 5, 1966, 93.

${ }^{17}$ DAvidson WeInBERG, G.: A wandering soldier's grave in Corinth. Hesperia 43, 1979.
} 
Byzantine products. ${ }^{18}$ The primary indication of their origin was the uniform style of their hilts; at the same time Kindî's descriptions leave no doubt that - in contrast to Viking swords - Arab swords were produced and traded without hilts. Even the identification of a specific type is often impossible without examining the tang. We do not know which trade routine was used in Byzantium, but in view of the geographical and typological connections the oriental one, without hilts, seems most probable. In any case, the style of the hilts does not indicate directly the origin of the blade, and these swords can hardly be compared with the Arabic ones without removing their hilt. Although some tendencies can be noted, only metallurgical analyses could resolve the problem. Also, we know that there was a wide variety of Byzantine swords since about eight different names for the ones used in the army are known. ${ }^{19}$

The expression Rûm al-quyûn, "the blacksmiths' Byzantium" is not a poetical exaggeration at all because we know from literary sources that iron enough for 4000 weapons was stored in Constantinople. ${ }^{20}$

As far as I know, the sources do not mention the material of these swords, daggers and knives, save for a very important, but little known piece of information that damascened steel swords had appeared in Europe before the arrival of the Arabs, from Sassanian Iran; the Byzantines knew as well as the Arabs that this technology originated from India. ${ }^{21}$ Damascening is first mentioned by Cassiodorus in the early 6 th century; ${ }^{22}$ it is comparable only with Imru' ul-Qays' verse cited by Bîrûnî, ${ }^{23}$ although the interpretation of this verse does not necessarily imply damascening, it could simply be the accidental lustre or veins of the shâburqân.

This does not mean that damascened swords were frequent in Europe - Cassiodorus' passage is a reference to a blade in royal property; we may assume that Sassanian techniques were not disseminated in the West for strategic reasons, if for nothing else; they spread more freely in the Caliphate after the conquest of Iran, and only after some centuries did they become general. It would nonetheless appear that there was a widespread knowledge and an exceptional use in Europe of the swords made from Oriental, 'Indian' (indanikos, idanikos, ferrum audanicum) iron. ${ }^{24}$

${ }^{18}$ JANKOVIĆ, Implements and Weapons, 60, mentions a 10th or 11 th century sword that was found at Kljac-Dunova in Serbia. It is not rare that swords with Byzantine decorations are claimed to be of Byzantine origin, such as the finds from Kunágota or Malaya Pereshchepina, although such claims are difficult to prove. The corpus of swords from the Carpathian Basin that are believed to be Byzantine products was assembled by Éva Garam and Attila Kiss (GARAM 1991; KISS 1987). These swords date from different periods, ranging from the early 7 th to the 10th century. However, the few surviving specimens do not enable typological classifications.

${ }^{19}$ KOLIAS 1988, 132.

${ }^{20}$ Kolias 1988,135 .

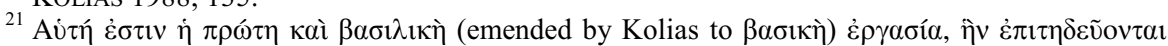

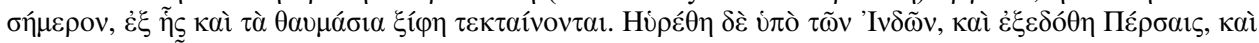

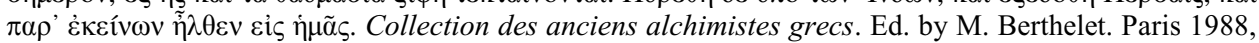
$348,5-8$.

${ }^{22}$ MommSen, TH.: MGH Auctores antiquissimi. Berlin 1961, 2. 1.143.

${ }^{23}$ Imru' ul-Qays, $4,9$.

${ }^{24}$ KAHANE-AUSTIN 1946,181-87; RUSEV 1961, 2. 8-14. THEODORIDIS 1971, 61-64, rejects this etymology of the word indanikos; in his opinion the sword is a Caucasian type (Ossetian ändän, Chechen 
In view of the above it is groundless to speak about soft iron swords, at least in relation to Byzantium. The empire would have been at an insuperable technological disadvantage to the Sassanians, if it had used soft iron blades (cp. Kindî's descriptions of the Fârsî and Khurâsânî types). We must therefore assume that Kindî simply ascribed the worst quality to the Occidental world automatically, without a personal knowledge of the arms used there.

The other question raised by the poetic qala ' $\hat{\imath}$ term, the question of whether the 'ancient' swords were in part Byzantine products, cannot be answered so definitely.

The length of the Byzantine sword types varied. The most important type, the double-edged spatha was in fact a 4 to 4.75 spans long sword; length of the hilt was about two-thirds of a span. ${ }^{25}$ The Byzantine span, measuring $23.4 \mathrm{~cm}$, was divided into 12 digits. ${ }^{26}$ We may assume that the early Islamic span was roughly the same length, although such an equivalence may pose some problems. In this case, the spatha of Constantinople and the qala $\hat{\imath}$ of the Arabs were almost identical in length, ${ }^{27}$ and the length of the normal sulaymânî, the modern yamânî and the longest ancient yamâni swords corresponded to the minimal length of a spatha. Unfortunately the Arabic authors offer very little information concerning the hilt.

Let us have a look at the surviving specimens. ${ }^{28}$ Most of the 'Barbaric' blades that are believed to be of Byzantine origin, are shorter than the average spatha and considerably narrower than the Arabic types. Three blades can be regarded as a spatha of minimal length: one from Csóka (4 spans long, 1.8 digits wide), one from Mali Idos (3 spans 11 digits long, 1.38 digits wide) and perhaps the damaged sword from Kunágota (with an original length of cca. 4 spans and a width of 2.5 digits). This latter specimen tapers towards its point and is therefore unrelated to the qala $\hat{\imath}$; if related to any known type, it is an uncommonly long yamân $\hat{\imath}$ with average width.

A few short and narrow swords are also known: their dimensions are fractions in the Byzantine and Arabic system, and they differ considerably from every Oriental type because of their narrow width (Tárnok: 3 spans 9.7 digits long, 1.44-1.55 digits wide; Csépa: 3 spans 8.6 digits long, 1.55-1.8 digits wide). Their origin is uncertain, but they can hardly have been Byzantine products. A few blades are similar to a light yamânî one, although they are slightly narrower (this is not an absolute obstacle to identification since the surviving Arabic swords are also slightly narrower than the regular standard): these blades include the specimens from Aradka (3 spans 6 digits long, 1.5-2 digits wide, tapering towards the point) and perhaps from Zillingtal, although the latter is very narrow ( 3 spans 6 digits long, 1.54 digits wide). Although its length is identical with that of a $F \hat{a} r s \hat{\imath}$ white sword, the great geographic distance and its narrowness makes any identification doubtful. The sword from Sepsiszentgyörgy-

\footnotetext{
ondanig), and could therefore only be related to the Qusâsî swords. Still, he does not reject entirely the possible presence of 'sidéros indikos' in the Byzantine empire.

${ }^{25}$ KOLIAS 1988, 137-38.

${ }^{26}$ SCHILBACH 1970, 19.

${ }^{27}$ Kindî 23 : the length of a qala $\hat{\imath}$ sword is $4-5$ spans. note 18 ).

${ }^{28}$ These blades are quoted according to the corpus compiled by Éva Garam and Attila Kiss (see
} 
Eprestetö ( 3 spans 3 digits long, 2.5 digits wide) is perhaps a similar type, but it is not an exact parallel of any oriental type.

The one-edged sword from Babarc is striking similar in form and length to the Kûfi white type (3 spans 4 digits), but its narrow width (1.8 digits) suggests that the (presumably) Byzantine one-edged type differed from the Oriental one, even though they had the same length.

Although any identification is impossible without removing the hilt, the 'Barbaric' swords that are shorter than a spatha seem to represent a Mediterranean - perhaps Byzantine - type that can be compared to the 'ancient yamâni' forged iron swords in terms of form and length, even it has a slightly smaller width and does not feature the characteristic grooves of the Arabic ones: it is therefore a related, but not identical type.

The few depictions from the 9th-11th centuries allow the approximate reconstruction of forms and sizes. ${ }^{29}$ These are mostly straight bladed, although some curved ones also occur, even if the latter seem a flight of fancy on the illustrator's part because their scabbards are shown in a straight form. Their approximate length is generally around 4 spans or even longer. One very early depiction from the 9th century shows a far shorter, cca. 3 spans long two-edged sword with a rhombic section, provided with conical top and a stiffening channel. ${ }^{30}$ Most of these representations compare well with the Arabic qala $i \hat{\imath}$ swords, although the latter one is more similar to a one-channelled yamânî, the so-called șamșâm or shahâdast sword. Still, this similarity means very little since Kindî did not record the sizes of the European type, he simply notes that they are also one-channelled. ${ }^{31}$

Several forms of the Byzantine swords can be quoted as parallels: a type with identical length and conic head (resembling the qala $\hat{\imath}$ or șamșam blades of the Arabs), a type tapering towards the point (bearing some resemblance to the sulaymânî swords), and a type with broad end and narrow head (corresponding to Kindî's description of Western European swords). ${ }^{32}$ The blade is sometimes inscribed and the hilt sometimes has a cross-guard. It does not contradict Kindî's description that the cross-guard is a peculiarity of the West European sword, ${ }^{33}$ and the inscriptions are designed to hide the veins, an important feature of the shâburqân blade that contains some narmâhan too.

In sum, we may say that the Byzantine swords cannot be identified with Kindî's 'Byzantine narmâhan' type, although many of them correspond to the 'alloyed Western European' type, and some are qala 'îlike in shape and size; in view of the Arabic data about their material, it is quite possible that this type had also been produced in the Byzantine empire, not only by the Arabs. Still, the currently available evidence does not allow any conclusion concerning a type similar to the sulaymânî.

${ }^{29}$ Kolias 1988, Pl. 24. 1, Pl. 38. 1; straight swords: Pl. 14. 1, Pl. 22. 1, Pl. 24. 2-3, Pl. 26. 2 , Pl. 30. 1.

${ }^{30}$ Kolias 1988, Pl. 7. 2.

${ }^{31}$ Kindî 32, 12.

${ }^{32}$ KOLIAS 1988, 144-45.

${ }^{33}$ Kindî 33, 1. 


\section{REFERENCES}

Allan, J. W.: Persian Metal Technology 700-1300 AD. London 1979.

ABÛ R-RAYHÂA AL-BîRûNî: Minneralogiya. Transl. by A. M. Belenitzky. Moskva 1963.

CAHEN, C.: Les changements techniques militaires dans le Proche-Orient médiéval et leur importance historique. War, Technology and Society in the Middle East. London 1978, 113-124.

GARAM, É.: A tiszakécske-óbögi avarkori sírok. ComArchHung 1991, 129-166.

KAHANE, H. \& R.-AUSTIN, H. D.: Byzantinos idanikos sidéros. Byzantina-Metabyzantina I, 1946, 181187.

KISS, A.: Byzantinische Schwerter im Karpatenbecken. AAH 39, 1987, 193-210.

KoliAS, T. G.: Byzantinische Waffen. 1988.

Les Pays du Nord et Byzance. Figura NS 19. Acta Universitatis Upsaliensis 1981. Zur Ausrüstung des Kriegers in Byzanz, im Kiewen Rußland und in Nordeuropa nach bildlichen und literarischen Quelle, P. Schreiner.

LOMBARD, M.: Les métaux dans l'ancien Monde du Ve au XI siècle. Paris 1974.

MAYER, L. A.: Saracenic Arms and Armour. Ars Islamica X, 1943, 1-12.

NiCOLLE, D.: Early Medieval Islamic Arms and Armour. Gladius. Madrid 1976.

RESCHER, N.: Al-Kindî, an Annotated Bibliography. Pittsburgh 1964.

RUSEV, V"rkhu tekhnologiyata na nyakov zhelezny predmety. Arkheologiya 3, 1961: 2, 8-14.

SAUVAIRE, Matériaux pour servir l'histoire de la numismatique et de la métrologie musulmanes. JA $1881-82$.

SCHILBACH, H.: Byzantinische Metrologie. Handbuch der Altertumswissenschaft 12. 4. München 1970.

SChWARZlose, F. W.: Die Waffen der alten Araber, aus ihren Dichtern dargestellt. Leipzig 1886.

SPRANDEL, R.: Das Eisengewerbe im Mittelalter. Stuttgart 1968.

STÖCKLEIN, H.: Die Waffenschätze im Topkapu Sarayi Müzesi zu Istanbul - Ein vorläufiger Bericht. Ars Islamica I, 1934, 200-218.

STÖCKLEIN, H.: Arms and Armour. A Survey of Persian Art III. 2555-2585. Edited by A. U. Pope. 1939.

THEODORIDIS, D.: Zum Problem von indanikos sidéros. BZ 64, 1971, 61-64.

Pázmány Péter Catholic University

H-2081 Piliscsaba 